\title{
Ortaokul Öğretmenlerinin Öğretim Programına Bağlılıklarının İncelenmesi
}

\section{Mecit ASLAN*, $\quad$ Rezzan Zeliha ERDEN**}

Öz: Bu araştırmanın amacı ortaokul öğretmenlerinin öğretim programına bağlılıklarının çeşitli değişkenlere göre incelenmesidir. Araştırmada betimsel tarama modeli kullanılmıştır. Araştırmanın örneklemini 2018-2019 eğitim-öğretim yılında Van ilinin köy, ilçe ve merkez ortaokullarında görev yapan 356 öğretmen oluşturmaktadır. Çalışmada veri toplama aracı olarak "Öğretim Programına Bağlılık Ölçeği" kullanılmıştır. Elde edilen verilerin analizinde betimsel istatistikler (aritmetik ortalama ve standart sapma), bağımsız gruplar için t testi ve tek yönlü varyans analizi (ANOVA) kullanılmıştır. Araştırmanın sonucunda ortaokul öğretmenlerinin genel olarak öğretim programına bağl1lık düzeylerinin yüksek olduğu görülmüştür. Alt boyutlar bazında incelendiğinde, en olumlu görüş belirtilen boyutların uygulamanın kalitesi ve katılımcıların tepkileri; en olumsuz görüş belirtilen boyutların ise süre ve öğretmen eğitimi boyutları olduğu belirlenmiştir. Ortaokul öğretmenlerinin öğretim programına bağlılıklarının cinsiyet, mesleki deneyim ve görev yapılan yerleşim yeri değişkenlerine göre anlamlı farklılık göstermediği; eğitim düzeyi ve branş değişkenlerine göre ise anlamlı farklılık gösterdiği tespit edilmiştir.

Anahtar Kelimeler: Öğretim programı, öğretim programına bağlılık, ortaokul öğretmenleri.

\section{Investigation of Secondary School Teachers' Curriculum Fidelity}

Abstract: The aim of this study is to investigate the curriculum fidelity of secondary school teachers according to various variables. The screening model was used in the research. The sample of the study consists of 356 teachers working in villages, districts and central secondary schools of Van province in 2018-2019 academic year. In the study, "Curriculum Fidelity Scale" was used as data collection tool. Descriptive statistics (mean and standard deviation), independent samples $t$ test and one-way

*Dr. Öğr. Üyesi, Van Yüzüncü Yıl Üniversitesi, Eğitim Fakültesi, Email:maslan4773@gmail.com Orcid No: 0000-0002-7970-5892 .

${ }^{* *}$ Milli Eğitim Bakanlığı Email:_ Orcid No:0000-0001-9451-6902

$\begin{array}{lll}\text { Gönderim:14.10.2019 Kabul:24.12.92019 } & \text { Yayın: 29.02.2020 }\end{array}$


ANOVA were used in the data analysis. In case ANOVA test revealed a significant difference, LSD Test was used for pairwise comparisons. As a result of the study, it was seen that the secondary school teachers generally had a high level of curriculum fidelity. When examined on the basis of sub-dimensions, it was determined that the most positive opinions relate with "the quality of the application" and "the reactions of the participants"; the most negative opinions relate with "time" and "teacher education" dimensions. It was found that the curriculum fidelity of secondary school teachers did not differ significantly according to gender, seniority and place of residence. On the other hand, it was determined that teachers' curriculum fidelity differed significantly according to education level and branch variables.

Keywords: Curriculum, curriculum fidelity, secondary school teachers.

\section{Giriş}

Eğitimde verimliliği arttırmak, eğitim faaliyetlerini düzenlemek ve eşgüdümü sağlamak için programlara ihtiyaç vardır. Ertürk (1984) eğitimin etkili ve verimli olabilmesi için plan/program fikrine ağırlık verilmesi gerektiğini dile getirmiştir. Programlar, eğitim felsefesi çerçevesinde belirlenen amaçları ve belirli ilkelere göre düzenlenmiş içeriği ve bu doğrultuda kullanılacak yöntemleri, destekleyici araçgereçleri, amaçlara ulaşılabilirlik düzeyini gösteren değerlendirme ölçütlerinin bütünü olarak ifade edilebilir (Gözütok, 2003). Uşun (2016) programı, bir işin niçin yapılacağını, içeriğinde neler olacağını ve nasıl?, nerede?, ne zaman?, kim? ile yapılacağını gösteren önceden tasarlanmış bir çizelge olarak tanımlamıştır. Bu bağlamda öğretim programının eğitimin gerçekleşmesinde önemli bir role sahip olduğu yadsınamaz. Okullardaki eğitim-öğretim faaliyetlerinin temelini oluşturan öğretim programı (Güzel ve Karadağ, 2013), bir dersin öğretme-öğrenme sürecinde nelerin yer alacağını ve bunların niçin, hangi şekilde yer alması gerektiğini gösteren bir kılavuzdur (Özçelik, 1992).

Hazırlanan öğretim programının eğitim sürecinde uygulanma durumu da önem arz etmektedir. Planlanan program ile uygulamaya konulan program arasindaki farklılığa dikkat edilerek programın uygulama aşamasında farklı durumların olabileceği dikkate alınmalıdır (Marsh ve Willis, 2007). Programın uygulanabilirliği “öğretim programına bağlılık" kavramı ile ilişkilidir. Öğretim programına bağlılık, öğretmenlerin 
programı onu geliştirenlerin amaçladığı şekilde uygulama derecesini açıklamaktadır (Pence, Justice ve Wiggins, 2008). Bir diğer ifadeyle öğretim programına bağlılık, “tasarlanan programın öğretmen/paydaşlar tarafından aslına sadık kalınarak uygulanması" olarak tanımlanabilir. Öğretim programına bağlılığın incelenmesi, program ve program uygulaması sonucunda oluşan ürün arasındaki ilişkiyi incelemekle kalmayıp süreçle ilgili sunduğu bilgi sayesinde, programın etkililik derecesi hakkında yanlış sonuçlara ulaşma olasılığını da azaltmaktadır (Bümen, Çakar ve Yıldız, 2014). Programa bağlılığı sürdürmek güçse, programın gerçekleştirilebilirliğinin zayıf olduğu sonucuna ulaşılır. Programa bağl1lık yüksek olduğu halde istenilen sonuç elde edilemiyorsa programın yeniden düzenlenmeye ihtiyacı olduğu sonucuna ulaşılır (Dusenbury, Brannigan, Falco ve Hansen, 2003).

Dusenbury ve diğerleri (2003) öğretim programına bağlılı̆̆ı a) uyma b) doz/süre c) uygulamanın kalitesi d) katılımcıların tepkisi e) program farklılıkları olmak üzere beş boyutta ölçülebildiğini belirtmişlerdir. Uyma; program ögelerinin etkinlik, materyal, araç-gereç vb. süreç içerisinde etkin bir şekilde kullanılarak uygulanmasıdır. Doz/süre; program uygulamalarının süresi, sayısı ve sıklığıdır. Uygulamanın kalitesi; programda kullanması önerilen yöntem tekniklerin uygulayıcılar tarafından kullanılma tarzı ile ilişkilidir. Katılımcıların tepkisi; programa katılan kişilerin yeniliğe bakış açılarıdır. Program farklılıkları ise; yeni öğretim programını benzer ya da eski öğretim programından ayırt eden kendine ait özelliklerdir.

Bilim ve teknolojide yaşanan gelişimler ve değişimler insan hayatını da etkilemektedir. Bu durum insanların eğitim felsefesinde değişimlere neden olmakta ve program tasarısını da doğrudan etkilemektedir. Günümüzde öğrenci merkezli program tasarısı programda yer almasına rağmen yapılan araştırmalarda öğretmen merkezli program tasarısının kullanıldığı sonucuna ulaşılmıştır. $\mathrm{Bu}$ çerçevede program tasarımının neden başarılı olamadığını araştırmak için öğretim programına bağlılık kavramının incelenmesinin önem arz ettiği söylenebilir (Bümen, Çakar ve Yıldız, 2014). Programda yaşanılan değişimleri okulların sadece isim olarak benimsediklerinde ve programa bağlılık olmadığında program tasarım özelliklerinden elde edilen sonuçların yetersiz kalacağı öngörülmektedir (Kovaleski, Gickling, Morrow ve Swank, 1999). 
Öğretim programının uygulamasını etkileyen faktörler olarak bölgesel koşullar, program özellikleri, öğretmen eğitimi, kurumsal özellikler, sosyo-ekonomik durum, öğrenci özellikleri, sınavlar ve eğitim sistemi sayılabilir (Bümen, Çakar ve Yıldız, 2014). Ringwalt ve diğerleri (2003) ise öğretim programına bağlılığı etkileyen faktörlerin okul bağlamı, programın uygulandığı sistem, program uygulayıcıları (öğretmenler) ve programın hedef kitlesi (öğrenciler) olduğunu ifade etmişlerdir. Dolayısıyla öğretim programına bağlılığı etkileyen en önemli faktörlerden birinin programı uygulayan öğretmenler olduğu söylenebilir. Öğretmenler öğretim programını temele alarak kendi deneyim ve yeterlilikleri ile öğrencilerin düzeyleri doğrultusunda ders içi etkinlikleri planlamalı ve uygulanmasını sağlamalıdır. Öğretim programının öğretmenler tarafından ne düzeyde benimsendiği ve uygulamaya ne düzeyde yansıtıldığını belirlemek harcanan emek, para ve zamanın boşa gitmemesi bakımından önemlidir (Dikbayır ve Bümen, 2016). Aynı zamanda öğretmenlerin öğretim programına bağlılıkları incelenerek program tasarısında yer alan yeniliklerin başarılı olup olmadığı konusunda da bilgi sahibi olunabilir (Burul, 2018).

Alanyazın incelendiğinde Türkiye'de öğretim programına bağlılık kavramına sınırlı sayıda çalışmada (Baş ve Şentürk, 2017; Bay, Kahramanoğlu, Döş ve TuranÖzpolat, 2017; Bümen, Çakar ve Y1ldız, 2014; Dikbayır ve Bümen, 2016; Yaşaroğlu ve Manav, 2015) yer verildiği, daha çok öğretim programının uygulanabilirlik durumlarının incelendiği, programlara ilişkin görüşler alındığ 1 ve programların değerlendirilmesine yönelik çalışmaların yapıldığı (Aslan ve Erden, 2018; Aslan ve Çıkar, 2017; Aslan ve Çökük, 2018; Caner ve Tertemiz, 2010; Çiftçi, Akgün ve Deniz, 2013; Çiftçioğlu, 2009; Dinç ve Doğan, 2010; Gömleksiz ve Bulut, 2007; GülbaşÇatak, 2008; Güneş ve Baki, 2011; Kamber, Acun ve Akar, 2011; Karacaoğlu ve Acar, 2010; Kaya, Artvinli ve Bulut, 2008; Kozikoğlu, 2014; Kurt ve Yıldırım, 2010; Meşin, 2008; Öztürk ve Demircioğlu, 2002; Öztürk-Akar, 2005; Taşçı, 2011; Zengin, 2010) görülmüştür. Dolayısıyla Türkiye'de öğretim programına bağlılık kavramını doğrudan ele alan sınırlı sayıda çalışmanın olması ve öğretim programına bağlılığın farklı yerleşim yerlerinde çalışan öğretmenlerin çeşitli değişkenler açısından incelenmesinin alanyazına katkı sunacağı söylenebilir. 


\section{Araştırmanın Amacı}

$\mathrm{Bu}$ çalışmanın amacı, ortaokul öğretmenlerinin öğretim programına bağlılık düzeylerini belirlemektir. Bu amaç doğrultusunda aşağıdaki sorulara yanıt aranmıştır:

1. Öğgretmenlerin öğretim programına bağlılık düzeyi nedir?

2. Ö Ögretmenlerin öğretim programına bağlılıkları;
a. cinsiyete,
b. mesleki deneyime,
c. eğitim düzeyine,
d. görev yapılan yerleşim yerine ve
e. branşa göre anlamlı farklılık göstermekte midir?

\section{Yöntem}

\section{Araştırmanın Modeli}

$\mathrm{Bu}$ araştırmada ortaokul öğretmenlerinin öğretim programına bağlılıklarının belirlenmesinde betimsel tarama modelinden yararlanılmıştır. Betimsel tarama modeli, var olan bir durumu ortaya çıkarmaya ve olduğu gibi betimlemeye çalışan bir araştırma modelidir (Karasar, 2005).

\section{Evren ve Örneklem}

Çalışmanın evrenini 2018-2019 eğitim-öğretim yılında Van ilinde ortaokullarda görev yapan 4807 ortaokul öğretmeni oluşturmaktadır. Çalışmada zaman ve emek açısından tasarruf etmek amacıyla örneklem alma yoluna gidilmiş ve örneklem belirlenirken tabakalı örnekleme yöntemi kullanılmıştır. Tabakalı örnekleme, evrendeki alt grupların belirlenerek evren büyüklüğü içerisindeki oranına göre örneklemde temsil edilmelerini sağlayan yöntemdir (Büyüköztürk, Kılıç-Çakmak, Akgün, Karadeniz ve Demirel, 2016). Çalışmada il merkezi, ilçe ve köy olmak üzere üç farklı tabaka belirlenmiştir. Çalışmanın örneklemini Van ilinde ortaokullarda çalışan öğretmenlerden 356 kişi oluşturmaktadır. Araştırmada yer alan öğretmenlerin demografik özellikleri Tablo 1'de sunulmuştur. 
Tablo 1.

Örneklemde Yer Alan Öğretmenlerin Demografik Özellikleri

\begin{tabular}{llcc}
\hline Demografik Özellik & Kategori & Sayı (n) & Yüzde (\%) \\
\hline \multirow{3}{*}{ Cinsiyet } & Kadın & 180 & 50.6 \\
\hline Görev Yaptığı Yerleşim & Erkek & 176 & 49.4 \\
Yeri & İl Merkezi & 202 & 56.7 \\
& İlçe & 109 & 30.6 \\
& Köy & 45 & 12.6 \\
\hline & İlköğretim Matematik Öğretmenliği & 62 & 17.4 \\
& İngilizce Öğretmenliği & 39 & 11.0 \\
& Fen Bilimleri Öğretmenliği & 48 & 13.5 \\
& Güzel Sanatlar Ö./Beden Eğitimi Ö. & 49 & 13.8 \\
& Sosyal Bilgiler Öğretmenliği & 43 & 12.1 \\
Branş & Din Kültürü ve Ahlak Bilgisi Öğretmenliği & 26 & 7.3 \\
& Türkçe Öğretmenliği & 59 & 16.6 \\
& Teknoloji Tasarım Ö/Bilişim Teknolojileri Ö. & 30 & 8.4 \\
\hline
\end{tabular}

Tablo 1'de görüldüğü gibi, katılımcı öğretmenler 180 (\%50.6) kadın ve 176 (\%49.4) erkekten oluşmaktadır. Katılımcıların 202'si (\%56.7) il merkezinde, 109'u (\%30.6) ilçede ve 45’i (\%12.6) köyde çalışmaktadır. Çalışmaya katılan öğretmenlerin branşa göre dağılımı şu şekildedir: İlköğretim matematik (n=62), İngilizce (n=39), fen bilimleri ( $n=48)$, güzel sanatlar/beden eğitimi ( $n=49)$, sosyal bilgiler $(n=43)$, din kültürü ve ahlak bilgisi $(n=26)$, Türkçe ( $n=59)$, ve teknoloji tasarım/bilişim teknolojileri $(n=30)$.

\section{Veri Toplama Aracı}

Araştırmada ortaokul öğretmenlerinin öğretim programına bağlılık düzeylerini belirlemek amacıyla “Öğretim Programına Bağlılık Ölçeği”” kullanılmıştır. Burul (2018) tarafından geliştirilen ölçek 7 alt boyuttan (uyma, doz/süre, uygulamanın kalitesi, katılımcıların tepkileri, program farklılıkları, öğretmen eğitimi ve okul iklimi) oluşmaktadır. Toplam 42 maddeden oluşan beşli likert tipindeki ölçeğin "uyma" boyutuyla ilgili 8 madde, "doz/süre" boyutuyla ilgili 5 madde, "uygulamanın kalitesi" boyutuyla ilgili 5 madde, "katılımcıların tepkisi" boyutuyla ilgili 7 madde, "program farklılıkları" boyutuyla ilgili 5 madde, "öğretmen eğitimi”" boyutuyla ilgili 8 madde ve "okul iklimi” boyutuyla ilgili 4 madde bulunmaktadır. Maddeler 1- Kesinlikle katılmıyorum ve 5- Kesinlikle katılıyorum aralığında puanlanmaktadır. Ölçeğin alt boyutlarının Cronbach Alpha iç tutarlılık katsayısı "uyma" boyutu için .84, "doz/süre" boyutu için .89, "uygulamanın kalitesi” boyutu için .81, "katılımcıların tepkisi” boyutu için .89, "program farklılıkları" boyutu için .86, "öğretmen eğitimi” boyutu için .90 , “okul iklimi” boyutu için .78 olarak belirlenmiştir. Bu çalışmada ölçeğin Cronbach Alfa değeri .81 olarak çıkmıştır. Bu değerler ölçme aracından elde edilen verilerin güvenilir olduğunu göstermektedir. 


\section{Verilerin Analizi}

Elde edilen verilerin analizinde SPSS 24 programı kullanılmıştır. Ortaokul öğretmenlerinin öğretim programına bağlılık düzeylerini belirlemek için aritmetik ortalama ve standart sapma değerlerine bakılmıştır. Öğretmenlerin öğretim programına bağl1lıklarının çeşitli değişkenlere göre değişip değişmediğini belirlemek için ise fark analizlerinden yararlanılmıştır. Fark analizleri yapılmadan önce verilerin normal dağılım gösterip göstermediği çarpıklık ve basıklık değerleri ile incelenmiştir. Bu değerlerin -1.00 ve +1.00 arasında olması nedeniyle verilerin normal dağılım gösterdiği kabul edilmiş ve parametrik testlere başvurulmuştur. Öğretmenlerin öğretim programına bağlılıklarının cinsiyet ve eğitim düzeyi değişkenlerine göre fark gösterip göstermediğini belirlemek için bağımsız gruplar için t testi; mesleki kıdem, görev yapılan yerleşim yeri ve branş değişkenlerine göre farklılık gösterip göstermediğini belirlenmek için ise tek yönlü varyans analizi (ANOVA) kullanılmıştır. ANOVA sonrası anlamlı farklılık çıkması durumunda ikili karşılaştırmalar için post-hoc LSD Testi kullanılmıştır. Analizlerde anlamlılık düzeyi .05 olarak kabul edilmiştir.

\section{Bulgular}

Çalışmanın bu bölümünde verilerin analizi sonucu elde edilen bulgulara yer verilmiştir. Araştırmanın birinci alt problemi olan "Ortaokul öğretmenlerinin öğretim programına bağlılıkları ne düzeydedir?” sorusuna yanıt vermek amacıyla başvurulan analiz sonuçları Tablo 2'de verilmiştir.

Tablo 2.

Öğretmenlerin Öğretim Programına Bağlılık Düzeylerine İlişkin Betimsel İstatistikler

\begin{tabular}{lccc}
\hline Boyutlar & $\mathbf{n}$ & $\bar{X}$ & Ss \\
\hline Öğretim programına bağlılık (Toplam) & 356 & 3.55 & .34 \\
Uyma & 356 & 3.42 & .44 \\
Süre & 356 & 3.34 & .40 \\
Uygulamanın kalitesi & 356 & 4.07 & .55 \\
Katılımcıların tepkileri & 356 & 3.90 & .43 \\
Program farklılıkları & 356 & 3.34 & .55 \\
Öğretmen eğitimi & 356 & 3.27 & .68 \\
Okul iklimi & 356 & 3.55 & .84 \\
\hline
\end{tabular}

Tablo 2 incelendiğinde öğretmenlerinin öğretim programına bağlllık ölçeğinden aldıkları puanların aritmetik ortalamasının 3.55 olduğu görülmektedir. Alt boyutlar açısından ele alındığında ise uyma boyutunun 3.42; süre boyutunun 3.34; uygulamanın 
kalitesi boyutunun 4.07; katılımc1ların tepkileri boyutunun 3.90; program farklılıkları boyutunun 3.34; öğretmen eğitimi boyutunun 3.27 ve okul iklimi boyutunun 3.55 aritmetik ortalamaya sahip olduğu görülmektedir. Bu bulgulardan hareketle ortaokul öğretmenlerinin öğretim programına bağlılı̆̆ın alt boyutlarından uygulamanın kalitesi ve katılımcıların tepkileri boyutlarına bağlılıklarının daha yüksek olduğu söylenebilir.

Ortaokul öğretmenlerinin öğretim programına bağl1lıklarının cinsiyete göre farklılık gösterip göstermediğine yönelik yapılan bağımsız gruplar için t testi sonuçları Tablo 3'te verilmiştir.

Tablo 3.

Cinsiyete Göre Öğretmenlerin Öğretim Programına Bağlılıklarına İlişkin Bağımsız Gruplar T Testi Sonuçları

\begin{tabular}{lccccccc}
\hline Boyutlar & Cinsiyet & $\mathbf{n}$ & $\bar{X}$ & Ss & Sd & t & p \\
\hline \multirow{2}{*}{ Uyma } & Kadın & 180 & 3.44 & .42 & 354 & 0.669 & .504 \\
& Erkek & 176 & 3.41 & .46 & & & \\
\hline \multirow{2}{*}{ Süre } & Kadın & 180 & 3.34 & .41 & 354 & -0.046 & .963 \\
& Erkek & 176 & 3.34 & .40 & & & \\
\hline \multirow{2}{*}{ Uygulamanın Kalitesi } & Kadın & 180 & 4.06 & .53 & 354 & -0.511 & .610 \\
& Erkek & 176 & 4.09 & .56 & & & \\
\hline \multirow{2}{*}{ Katılımcıların Tepkileri } & Kadın & 180 & 3.89 & .42 & 354 & -0.664 & .507 \\
& Erkek & 176 & 3.92 & .44 & & & \\
\hline \multirow{2}{*}{ Program Farklılıkları } & Kadın & 180 & 3.35 & .52 & 354 & 0.235 & .815 \\
& Erkek & 176 & 3.34 & .57 & & & \\
\multirow{2}{*}{ Öğretmen Eğitimi } & Kadın & 180 & 3.24 & .63 & 354 & -1.027 & .305 \\
\hline \multirow{2}{*}{ Okul İklimi } & Erkek & 176 & 3.32 & .72 & & & .314 \\
\hline \multirow{2}{*}{ Öğretim Programına Bağlılık } & Kadın & 180 & 3.51 & .79 & 354 & -1.009 & .314 \\
(Toplam) & Erkek & 176 & 3.60 & .88 & & & .508 \\
\hline
\end{tabular}

Tablo 3 incelendiğinde ortaokul öğretmenlerinin öğretim programına bağl1lık düzeylerinin ölçek toplamında ve hiçbir alt boyutta cinsiyete göre anlamlı bir farkl1lık göstermediği görülmektedir ( $\mathrm{p}>.05)$. Bu bulgu kadın ve erkek öğretmenlerin öğretim programına bağl1lıklarının benzer olduğunu göstermektedir.

Ortaokul öğretmenlerinin öğretim programına bağl1lık düzeylerinin mesleki deneyim değişkenine göre anlamlı farklılık gösterip göstermediğine yönelik yapılan ANOVA testi sonuçları Tablo 4'te verilmiştir. 
Tablo 4.

Mesleki Deneyime Göre Ortaokul Öğretmenlerinin Öğretim Programına Bağl1lıklarına İlişkin ANOVA Testi Sonuçları

\begin{tabular}{|c|c|c|c|c|c|c|c|c|c|c|}
\hline $\begin{array}{l}\text { Ölçek } \\
\text { Boyutları }\end{array}$ & $\begin{array}{l}\text { Mesleki } \\
\text { deneyim }\end{array}$ & n & $\bar{X}$ & Ss & $\begin{array}{c}\text { Varyansın } \\
\text { Kaynağı }\end{array}$ & KO & KT & Sd & $\mathbf{F}$ & $\mathbf{p}$ \\
\hline Uyma & $\begin{array}{l}1-5 \text { y1l } \\
6-10 \text { yıl } \\
11 \text { yıl ve üstü }\end{array}$ & $\begin{array}{c}214 \\
87 \\
55\end{array}$ & $\begin{array}{l}3.43 \\
3.48 \\
3.31\end{array}$ & $\begin{array}{l}.43 \\
.41 \\
.50\end{array}$ & $\begin{array}{l}\text { G. arası } \\
\text { G. içi } \\
\text { Toplam }\end{array}$ & $\begin{array}{l}.508 \\
.192\end{array}$ & $\begin{array}{c}1.016 \\
67.766 \\
68.782\end{array}$ & $\begin{array}{c}2 \\
353 \\
355\end{array}$ & 2.645 & .072 \\
\hline Süre & $\begin{array}{l}1-5 \text { y1l } \\
6-10 \text { yıl } \\
11 y 1 \text { ve üstü }\end{array}$ & $\begin{array}{c}214 \\
87 \\
55\end{array}$ & $\begin{array}{l}3.33 \\
3.34 \\
3.38\end{array}$ & $\begin{array}{l}.38 \\
.40 \\
.47\end{array}$ & $\begin{array}{c}\text { G. arası } \\
\text { G. içi } \\
\text { Toplam }\end{array}$ & $\begin{array}{l}.057 \\
.160\end{array}$ & $\begin{array}{c}.114 \\
56.621 \\
56.736\end{array}$ & $\begin{array}{c}2 \\
353 \\
355\end{array}$ & .356 & .701 \\
\hline $\begin{array}{l}\text { Uygulamanın } \\
\text { Kalitesi }\end{array}$ & $\begin{array}{l}1-5 \text { y1l } \\
6-10 \text { yıl } \\
11 \text { yıl ve üstü }\end{array}$ & $\begin{array}{c}214 \\
87 \\
55\end{array}$ & $\begin{array}{l}4.04 \\
4.04 \\
4.22\end{array}$ & $\begin{array}{l}.55 \\
.49 \\
.61\end{array}$ & $\begin{array}{l}\text { G. arası } \\
\text { G. içi } \\
\text { Toplam }\end{array}$ & $\begin{array}{l}.727 \\
.298\end{array}$ & $\begin{array}{c}1.454 \\
105.196 \\
106.650\end{array}$ & $\begin{array}{c}2 \\
353 \\
355\end{array}$ & 2.440 & .089 \\
\hline $\begin{array}{l}\text { Katılımcıların } \\
\text { Tepkileri }\end{array}$ & $\begin{array}{l}1-5 \text { y1l } \\
6-10 \text { y1l } \\
11 \text { y1l ve üstü }\end{array}$ & $\begin{array}{c}214 \\
87 \\
55\end{array}$ & $\begin{array}{l}3.90 \\
3.90 \\
3.92\end{array}$ & $\begin{array}{l}.45 \\
.37 \\
.44\end{array}$ & $\begin{array}{l}\text { G. arası } \\
\text { G. içi } \\
\text { Toplam }\end{array}$ & $\begin{array}{l}.004 \\
.182\end{array}$ & $\begin{array}{c}.008 \\
64.404 \\
64.412\end{array}$ & $\begin{array}{c}2 \\
353 \\
355\end{array}$ & .021 & .979 \\
\hline $\begin{array}{l}\text { Program } \\
\text { Farklılıkları }\end{array}$ & $\begin{array}{l}1-5 \text { y1l } \\
6-10 \text { yıl } \\
11 y 1 \text { ve üstü }\end{array}$ & $\begin{array}{c}214 \\
87 \\
55\end{array}$ & $\begin{array}{l}3.36 \\
3.37 \\
3.25\end{array}$ & $\begin{array}{l}.56 \\
.53 \\
.53\end{array}$ & $\begin{array}{c}\text { G. arası } \\
\text { G. içi } \\
\text { Toplam }\end{array}$ & $\begin{array}{l}.285 \\
.298\end{array}$ & $\begin{array}{c}.570 \\
105.328 \\
105.899\end{array}$ & $\begin{array}{c}2 \\
353 \\
355\end{array}$ & .956 & .386 \\
\hline $\begin{array}{l}\text { Öğretmen } \\
\text { Eğitimi }\end{array}$ & $\begin{array}{l}1-5 \text { y1l } \\
6-10 \text { yıl } \\
11 y 1 l \text { ve üstü }\end{array}$ & $\begin{array}{c}214 \\
87 \\
55\end{array}$ & $\begin{array}{l}3.34 \\
3.19 \\
3.16\end{array}$ & $\begin{array}{l}.64 \\
.70 \\
.77\end{array}$ & $\begin{array}{l}\text { G. arası } \\
\text { G. içi } \\
\text { Toplam }\end{array}$ & $\begin{array}{c}1.13 \\
6 \\
.454\end{array}$ & $\begin{array}{c}2.272 \\
160.246 \\
162.517\end{array}$ & $\begin{array}{c}2 \\
353 \\
355\end{array}$ & 2.502 & .083 \\
\hline Okul İklimi & $\begin{array}{l}1-5 \text { y1l } \\
6-10 \text { y1l } \\
11 y 1 \text { ve üstü }\end{array}$ & $\begin{array}{c}214 \\
87 \\
55\end{array}$ & $\begin{array}{l}3.60 \\
3.43 \\
3.54\end{array}$ & $\begin{array}{l}.81 \\
.88 \\
.88\end{array}$ & $\begin{array}{c}\text { G. arası } \\
\text { G. içi } \\
\text { Toplam }\end{array}$ & $\begin{array}{l}.916 \\
.701\end{array}$ & $\begin{array}{c}1.832 \\
247.545 \\
249.377\end{array}$ & $\begin{array}{c}2 \\
353 \\
355\end{array}$ & 1.306 & .272 \\
\hline $\begin{array}{l}\text { Öğretim } \\
\text { Programına } \\
\text { Bağll11k } \\
\text { (Toplam) } \\
\end{array}$ & $\begin{array}{l}1-5 \text { y1l } \\
6-10 \text { yıl } \\
11 \text { yıl ve üstü }\end{array}$ & $\begin{array}{c}214 \\
87 \\
55\end{array}$ & $\begin{array}{l}3.56 \\
3.53 \\
3.52\end{array}$ & $\begin{array}{l}.34 \\
.32 \\
.38\end{array}$ & $\begin{array}{l}\text { G. arası } \\
\text { G. içi } \\
\text { Toplam }\end{array}$ & $\begin{array}{l}.059 \\
.115\end{array}$ & $\begin{array}{c}.118 \\
40.506 \\
40.624\end{array}$ & $\begin{array}{c}2 \\
353 \\
355\end{array}$ & .515 & .598 \\
\hline
\end{tabular}

Tablo 4 incelendiğinde, uyma, program farklılıkları ve öğretmen eğitimi boyutlarında "11 yıl ve üstü” mesleki deneyime sahip öğretmenlerin daha düşük ortalamaya sahip oldukları; aynı öğretmenlerin uygulamanın kalitesi ve katılımcıların tepkileri boyutlarında ise daha yüksek ortalamalara sahip oldukları görülmektedir. Bununla birlikte ortaokul öğretmenlerinin öğretim programına bağlılık düzeylerinin bütün boyutlarda ve ölçek toplamında mesleki kıdeme göre anlamlı farklılık göstermediği tespit edilmiştir ( $\mathrm{p}>$.05).

Ortaokul öğretmenlerinin öğretim programına bağl1lık düzeylerinin eğitim düzeyi değişkenine göre anlamlı farklılık gösterip göstermediğine yönelik yapılan $t$ testi sonuçları Tablo 5'te verilmiştir. 
Tablo 5.

Eğitim Düzeyine Göre Ortaokul Öğretmenlerinin Öğretim Programına Bağl1lıklarına İlişkin Bağımsız Gruplar İçin T Testi Sonuçları

\begin{tabular}{|c|c|c|c|c|c|c|c|}
\hline $\begin{array}{l}\text { Ölçek } \\
\text { Boyutları }\end{array}$ & Eğitim Düzeyi & $\mathbf{n}$ & $\bar{X}$ & Ss & Sd & $\mathbf{t}$ & $\mathbf{p}$ \\
\hline Uyma & $\begin{array}{l}\text { Lisans } \\
\text { Yüksek Lisans/Doktora }\end{array}$ & $\begin{array}{c}336 \\
20\end{array}$ & $\begin{array}{l}3.42 \\
3.43\end{array}$ & $\begin{array}{l}.44 \\
.49\end{array}$ & 354 & -0.023 & .981 \\
\hline Süre & $\begin{array}{l}\text { Lisans } \\
\text { Yüksek Lisans/Doktora }\end{array}$ & $\begin{array}{c}336 \\
20\end{array}$ & $\begin{array}{l}3.33 \\
3.40\end{array}$ & $\begin{array}{l}.40 \\
.40\end{array}$ & 354 & -0.718 & .473 \\
\hline $\begin{array}{l}\text { Uygulamanın } \\
\text { Kalitesi }\end{array}$ & $\begin{array}{l}\text { Lisans } \\
\text { Yüksek Lisans/Doktora }\end{array}$ & $\begin{array}{c}336 \\
20\end{array}$ & $\begin{array}{l}4.06 \\
4.36\end{array}$ & $\begin{array}{l}.55 \\
.45\end{array}$ & 354 & -2.431 & .016 \\
\hline $\begin{array}{l}\text { Katılımcıların } \\
\text { Tepkileri }\end{array}$ & $\begin{array}{l}\text { Lisans } \\
\text { Yüksek Lisans/Doktora }\end{array}$ & $\begin{array}{c}336 \\
20\end{array}$ & $\begin{array}{l}3.90 \\
4.08\end{array}$ & $\begin{array}{l}.43 \\
.41\end{array}$ & 354 & -1.870 & .062 \\
\hline $\begin{array}{l}\text { Program } \\
\text { Farklılıkları }\end{array}$ & $\begin{array}{l}\text { Lisans } \\
\text { Yüksek Lisans/Doktora }\end{array}$ & $\begin{array}{c}336 \\
20\end{array}$ & $\begin{array}{l}3.34 \\
3.35\end{array}$ & $\begin{array}{l}.55 \\
.50\end{array}$ & 354 & -0.047 & .962 \\
\hline $\begin{array}{l}\text { Öğretmen } \\
\text { Eğitimi }\end{array}$ & $\begin{array}{l}\text { Lisans } \\
\text { Yüksek Lisans/Doktora }\end{array}$ & $\begin{array}{c}336 \\
20\end{array}$ & $\begin{array}{l}3.28 \\
3.19 \\
\end{array}$ & $\begin{array}{l}.67 \\
.76 \\
\end{array}$ & 354 & 0.578 & .564 \\
\hline Okul İklimi & $\begin{array}{l}\text { Lisans } \\
\text { Yüksek Lisans/Doktora }\end{array}$ & $\begin{array}{c}336 \\
20\end{array}$ & $\begin{array}{l}3.55 \\
3.54\end{array}$ & $\begin{array}{l}.84 \\
.78 \\
\end{array}$ & 354 & 0.075 & .940 \\
\hline Genel Ortalama & $\begin{array}{l}\text { Lisans } \\
\text { Yüksek Lisans/Doktora }\end{array}$ & $\begin{array}{c}336 \\
20\end{array}$ & $\begin{array}{l}3.54 \\
3.60\end{array}$ & $\begin{array}{l}.34 \\
.30 \\
\end{array}$ & 354 & -0.734 & .463 \\
\hline
\end{tabular}

Tablo 5 incelendiğinde, ortaokul öğretmenlerinin eğitim düzeyine göre öğretim programına bağlılık düzeylerinde uyma, süre, katılımcıların tepkileri, program farklılıkları, öğretmen eğitimi ve okul iklimi alt boyutlarında anlamlı bir farklılık olmadığı görülmektedir ( $\mathrm{p}>.05)$. Uygulamanın kalitesi alt boyutunda ise yüksek lisans/doktora mezunu olan öğretmenler lehine anlamlı bir fark olduğu görülmektedir $(\mathrm{p}<.05)$. Bu bulgu lisansüstü eğitim alan öğretmenlerin kaliteli öğretim uygulamaları yapmaya daha çok özen gösterdiklerini göstermektedir.

Ortaokul öğretmenlerinin öğretim programına bağlılık düzeylerinin görev yaptıkları yerleşim yeri değişkenine göre anlamlı farklılık gösterip göstermediğine yönelik yapılan ANOVA testi sonuçları Tablo 6'da verilmiştir. 
Tablo 6.

Görev Yapılan Yerleşim Yerine Göre Ortaokul Öğretmenlerinin Öğretim Programına Bağlılıklarına İlişskin ANOVA Testi Sonuçları

\begin{tabular}{|c|c|c|c|c|c|c|c|c|c|c|}
\hline $\begin{array}{l}\text { Ölçek } \\
\text { Boyutları }\end{array}$ & $\begin{array}{l}\text { Yerleşim } \\
\text { Yeri }\end{array}$ & $\mathbf{n}$ & $\bar{X}$ & Ss & $\begin{array}{c}\text { Varyansın } \\
\text { Kaynağı }\end{array}$ & KO & KT & Sd & $\mathbf{F}$ & p \\
\hline \multirow{3}{*}{ Uyma } & İl Merkezi & 202 & 3.43 & .45 & G. aras1 & .081 & .162 & 2 & .418 & .659 \\
\hline & İlçe & 109 & 3.43 & .42 & G. içi & .194 & 68.620 & 353 & & \\
\hline & Köy & 45 & 3.37 & .40 & Toplam & & 68.782 & 355 & & \\
\hline \multirow{3}{*}{ Süre } & İl Merkezi & 202 & 3.35 & .41 & G. aras1 & .060 & .119 & 2 & .371 & .690 \\
\hline & İlçe & 109 & 3.32 & .37 & G. içi & .160 & 56.617 & 353 & & \\
\hline & Köy & 45 & 3.31 & .39 & Toplam & & 56.736 & 355 & & \\
\hline \multirow{3}{*}{$\begin{array}{l}\text { Uygulamanın } \\
\text { Kalitesi }\end{array}$} & İl Merkezi & 202 & 4.09 & .52 & G. aras1 & .065 & .129 & 2 & .214 & .807 \\
\hline & İlçe & 109 & 4.07 & .58 & G. içi & .302 & 106.521 & 353 & & \\
\hline & Köy & 45 & 4.03 & .57 & Toplam & & 106.650 & 355 & & \\
\hline \multirow{3}{*}{$\begin{array}{l}\text { Katılımciların } \\
\text { Tepkileri }\end{array}$} & İl Merkezi & 202 & 3.89 & .41 & G. aras1 & .069 & .139 & 2 & .381 & .684 \\
\hline & İlçe & 109 & 3.93 & .43 & G. içi & .182 & 64.273 & 353 & & \\
\hline & Köy & 45 & 3.91 & .43 & Toplam & & 64.412 & 355 & & \\
\hline \multirow{3}{*}{$\begin{array}{l}\text { Program } \\
\text { Farkl111kları }\end{array}$} & İl Merkezi & 202 & 3.34 & .52 & G. aras1 & .790 & 1.580 & 2 & 2.673 & .070 \\
\hline & İlçe & 109 & 3.42 & .51 & G. içi & .296 & 104.319 & 353 & & \\
\hline & Köy & 45 & 3.20 & .68 & Toplam & & 105.899 & 355 & & \\
\hline \multirow{3}{*}{$\begin{array}{l}\text { Öğretmen } \\
\text { Eğitimi }\end{array}$} & İl Merkezi & 202 & 3.23 & .69 & G. aras1 & .614 & 1.228 & 2 & 1.343 & .262 \\
\hline & İlçe & 109 & 3.31 & .59 & G. içi & .457 & 161.290 & 353 & & \\
\hline & Köy & 45 & 3.40 & .75 & Toplam & & 162.517 & 355 & & \\
\hline \multirow{3}{*}{ Okul İklimi } & İl Merkezi & 202 & 3.53 & .83 & G. aras1 & .195 & .389 & 2 & .276 & .759 \\
\hline & İlçe & 109 & 3.57 & .75 & G. içi & .705 & 248.988 & 353 & & \\
\hline & Köy & 45 & 3.62 & 1.04 & Toplam & & 249.377 & 355 & & \\
\hline \multirow{3}{*}{ Toplam } & İl Merkezi & 202 & 3.54 & .33 & G. aras1 & .036 & .073 & 2 & .316 & .729 \\
\hline & İlçe & 109 & 3.57 & .32 & G. içi & .115 & 40.551 & 353 & & \\
\hline & Köy & 45 & 3.54 & .38 & Toplam & & 40.624 & 355 & & \\
\hline
\end{tabular}

Tablo 6 incelendiğinde, uyma, süre, uygulamanın kalitesi ve program farklılıkları boyutlarında köyde görev yapan öğretmenlerin daha düşük ortalamalara sahip oldukları görülmektedir. Söz konusu boyutlarda köyde görev yapan öğretmenler daha düşük ortalamalara sahip olmakla birlikte, hem bu boyutlarda, hem diğer boyutlarda hem de ölçek toplamında öğretmenlerin öğretim programına bağl1lıklarında görev yaptıkları yerleşim yerine göre anlamlı bir farklılık olmadığı saptanmıştır ( $\mathrm{p}>.05)$.

Ortaokul öğretmenlerinin öğretim programına bağl1lık düzeylerinin branş değişkenine göre anlamlı farklılık gösterip göstermediğine yönelik ANOVA testi yapılmıştır. Tablo 7'de verilmiştir. 
Tablo 7.

Branşa Göre Ortaokul Öğretmenlerinin Öğretim Programına Bağl1lıklarına İlişkin ANOVA Testi Sonuçları

\begin{tabular}{|c|c|c|c|c|c|c|c|}
\hline $\begin{array}{l}\text { Ölçek } \\
\text { Boyutları }\end{array}$ & $\begin{array}{l}\text { Varyansın } \\
\text { Kaynağı }\end{array}$ & KO & KT & Sd & $\mathbf{F}$ & p & Anlamlı Fark \\
\hline Uyma & $\begin{array}{l}\text { Gruplar arası } \\
\text { Gruplar içi } \\
\text { Toplam }\end{array}$ & $\begin{array}{l}.383 \\
.190\end{array}$ & $\begin{array}{l}2.680 \\
66.102 \\
68.782\end{array}$ & $\begin{array}{l}7 \\
348 \\
355\end{array}$ & 2.016 & .052 & \\
\hline Süre & $\begin{array}{l}\text { Gruplar arası } \\
\text { Gruplar içi } \\
\text { Toplam }\end{array}$ & $\begin{array}{l}.196 \\
.159\end{array}$ & $\begin{array}{l}1.373 \\
55.363 \\
56.736\end{array}$ & $\begin{array}{l}7 \\
348 \\
355\end{array}$ & 1.233 & .284 & \\
\hline $\begin{array}{l}\text { Uygulamanın } \\
\text { Kalitesi }\end{array}$ & $\begin{array}{l}\text { Gruplar arası } \\
\text { Gruplar içi } \\
\text { Toplam }\end{array}$ & $\begin{array}{l}.302 \\
.300\end{array}$ & $\begin{array}{l}2.117 \\
104.533 \\
106.650\end{array}$ & $\begin{array}{l}7 \\
348 \\
355\end{array}$ & 1.007 & .426 & \\
\hline $\begin{array}{l}\text { Katılımciların } \\
\text { Tepkileri }\end{array}$ & $\begin{array}{l}\text { Gruplar arası } \\
\text { Gruplar içi } \\
\text { Toplam }\end{array}$ & $\begin{array}{l}.165 \\
.182\end{array}$ & $\begin{array}{l}1.158 \\
63.254 \\
64.412 \\
\end{array}$ & $\begin{array}{l}7 \\
348 \\
355 \\
\end{array}$ & .910 & .499 & \\
\hline $\begin{array}{l}\text { Program } \\
\text { Farklılıkları }\end{array}$ & $\begin{array}{l}\text { Gruplar arası } \\
\text { Gruplar içi } \\
\text { Toplam }\end{array}$ & $\begin{array}{l}.324 \\
.298\end{array}$ & $\begin{array}{l}2.266 \\
103.633 \\
105.899\end{array}$ & $\begin{array}{l}7 \\
348 \\
355\end{array}$ & 1.087 & .371 & \\
\hline $\begin{array}{l}\text { Öğretmen } \\
\text { Eğitimi }\end{array}$ & $\begin{array}{l}\text { Gruplar arası } \\
\text { Gruplar içi } \\
\text { Toplam }\end{array}$ & $\begin{array}{l}1.081 \\
.445\end{array}$ & $\begin{array}{l}7.569 \\
154.948 \\
162.517\end{array}$ & $\begin{array}{l}7 \\
348 \\
355 \\
\end{array}$ & 2.833 & .019 & $\begin{array}{l}1-4,6-4,2-8 \\
3-8,4-8,5-8\end{array}$ \\
\hline Okul İklimi & $\begin{array}{l}\text { Gruplar arası } \\
\text { Gruplar içi } \\
\text { Toplam }\end{array}$ & $\begin{array}{l}2.181 \\
.673\end{array}$ & $\begin{array}{l}15.265 \\
234.112 \\
249.377\end{array}$ & $\begin{array}{l}7 \\
348 \\
355\end{array}$ & 3.241 & .002 & $\begin{array}{l}1-3,8-3,1-4 \\
2-4,5-4,6-4 \\
7-4,8-4\end{array}$ \\
\hline Toplam & $\begin{array}{l}\text { Gruplar arası } \\
\text { Gruplar içi } \\
\text { Toplam }\end{array}$ & $\begin{array}{l}.240 \\
.112\end{array}$ & $\begin{array}{l}1.682 \\
38.942 \\
40.624\end{array}$ & $\begin{array}{l}7 \\
348 \\
355\end{array}$ & 2.147 & .038 & $\begin{array}{l}1-3,6-3,8-3 \\
1-4,8-4\end{array}$ \\
\hline
\end{tabular}

Tablo 7'de görüldüğü üzere ortaokul öğretmenlerinin öğretim programına bağlılıkları uyma, süre, uygulamanın kalitesi, katılımcıların tepkileri ve program farklılıkları boyutlarında branş değişkenine göre anlamlı bir farklılık göstermezken (p>.05); öğretmen eğitimi ve okul iklimi boyutları ile ölçek toplamında anlamlı bir farklılık göstermektedir $(\mathrm{p}<.05)$. Bu farklılığın kaynağının belirlenmesi amacıyla başvurulan LSD Testi sonucuna göre öğretmen eğitimi boyutunda teknoloji tasarım/bilişim teknolojileri öğretmenleri ile İngilizce, fen bilimleri, güzel sanatlar/beden eğitimi ve sosyal bilgiler öğretmenleri arasında teknoloji tasarım/bilişim teknolojileri öğretmenleri aleyhine anlamlı farklılık tespit edilmiştir. Ayrıca aynı boyutta güzel sanatlar/beden eğitimi öğretmenleri ile ilköğretim matematik ve din kültürü ve ahlak bilgisi öğretmenleri arasında güzel sanatlar/beden eğitimi öğretmenleri lehine fark bulunmuştur. Okul iklimi boyutu incelendiğinde, güzel sanatlar/beden eğitimi öğretmenleri ile fen bilimleri öğretmenleri dışındaki tüm branş öğretmenleri arasında güzel sanatlar/beden eğitimi öğretmenleri lehine fark olduğu saptanmıştır. 
Ayrıca, okul iklimi boyutunda fen bilimleri öğretmenleri ile ilköğretim matematik ve teknoloji tasarım/bilişim teknolojileri öğretmenleri arasında fen bilimleri öğretmenleri lehine anlamlı farklılık belirlenmiştir. Ölçek toplamından alınan puanlara ilişkin ikili karşılaştırma sonuçları incelendiğinde ise fen bilimleri öğretmenlerinin öğretim programına bağlılıklarının ilköğretim matematik, din kültürü ve ahlak bilgisi ile teknoloji tasarım/bilişim teknolojileri öğretmenlerinden daha fazla olduğu görülmektedir. Ayrıca, güzel sanatlar/beden eğitimi öğretmenlerinin öğretim programına bağlılıklarının ilköğretim matematik ve teknoloji tasarım/bilişim teknolojileri öğretmenlerinden daha fazla olduğu belirlenmiştir.

\section{Tartışma, Sonuç ve Öneriler}

$\mathrm{Bu}$ araştırmada ortaokul öğretmenlerinin öğretim programına bağlılıklarının çeşitli değişkenler açısından incelenmesi amaçlanmıştır. Gerçekleştirilen analiz sonuçları incelendiğinde, öğretmenlerin öğretim programına bağl1lık düzeylerinin yüksek olduğu görülmüştür. Alanyazında bu araştırma sonucu ile tutarlı araştırma sonuçlarının (Akpınar ve Aydın, 2007, Burul, 2018; Çelik-Şen ve Şahin-Taşkın, 2010; Kenan ve Özmen, 2010; Öztürk, 2012; Tekbıyık ve Akdeniz, 2008) olduğu görülmektedir. Atilla (2012), Han (2013) ve Aykaç ve Ulubey (2012) tarafından yapılan çalışmalarda ise bu araştırmada ulaşılan sonuçtan farklı olarak öğretmenlerin öğretim programına bağlılık düzeylerinin düşük olduğu belirlenmiştir. Eğitim yöneticilerinin ve velilerin öğretmenlerden temel beklentisinin programlara uygun bir eğitim yapmaları ve kendilerine verilen süre içerisinde programı yetiştirmeleri olduğu düşünüldüğünde, öğretmenlerin programa bağlılıklarının yüksek olmasının anlaşılır bir durum olduğu söylenebilir.

Öğretmenlerin öğretim programına bağlılık düzeyleri yüksek olmakla birlikte, ölçeğin alt boyutlarına odaklanıldığında uyma, uygulamanın kalitesi, katılımcıların tepkileri ve okul iklimi boyutları ile ilgili puan ortalamaların yüksek düzeyde olduğu; süre, program farklılıkları ve öğretmen eğitimi boyutlarına ilişkin puan ortalamalarının ise orta düzeyde kaldığı görülmektedir. Bu sonuçlar öğretmenlerin programda yer verilen etkinlik ve uygulamalara uygun bir öğretim yapmaya çalıştıklarını, öğretme öğrenme sürecinde farklı yöntem ve tekniklere yer verdiklerini, öğrencilerin özelliklerini dikkate aldıklarını ve okul iklimini olumlu bulduklarını göstermektedir. Bal (2008) yaptığı çalışmada öğretmenlerin yeni programa ilişkin olumlu bir yaklaşım 
içinde olduklarını belirtmiştir. Akpınar ve Gezer (2010) de yaptıkları çalışmada öğretmenlerin yeni eğitim yaklaşımda ön plana çıkan kavramları benimsediklerini dile getirmişlerdir. Dolayısıyla çeşitli araştırmalarla tutarlı olarak (Akpınar ve Gezer, 2010; Bal, 2008; Burul, 2018; Çiftçi ve Tatar, 2015) bu çalışmada da öğretmenlerin yapılandırmacı yaklaşımı ve öğrenci merkezli eğitimi benimsedikleri söylenebilir.

Çalışmada ulaşılan sonuç öğretmenlerin programın uygulanmasında öngörülen süreye dikkat etme ve mevcut programı öncekilerden ayıran özelliklerini dikkate alma özelliklerinin yeterli düzeyde olmadığını göstermektedir. Öğretmenlerin belirtilen sürelere bire bir uymaması öğretim yaptıkları koşullar ve öğrenci profili ile ilişkilendirilebilir. Çünkü farklı koşullara sahip okullarda farklı hazırbulunuşluğa sahip öğrencilere öğretim yapılırken öngörülen sürenin dışına çıkılabilmektedir. Okulların koşulları iyileştikçe ve öğrencilerin başarı seviyesi arttıkça yeni konulara/etkinliklere ayrılacak zaman azalacaktır. Yetersiz koşullara sahip okullarda ve düşük akademik başarıya sahip öğrenciler için ise daha çok zaman ayrılması gerektiği söylenebilir. Öğretmenlerin program farklılıklarını yeterince bilmemesi ise öğretmen eğitimi ile ilişkilendirilebilir. Nitekim çalışmada öğretmen eğitiminin de yeterli görülmediği tespit edilmiştir. Öğretmen eğitimi boyutu lisans düzeyinde alınan eğitimin yetersiz olduğu ve lisans düzeyinde öğretim programlarının uygulaması ile ilgili bilgi eksikliklerin tamamlanması için öğretim programı ile ilgili derslerin arttırılması gerektiğini göstermektedir. Baki (2010) yaptığı çalışmasında öğretmen eğitiminin önemini vurgulamış ve öğretmenlere sadece alanı öğretmeyi değil uygulamada yapılacak esasları da kazandırması gerektiği üzerinde durarak bu çalışma ile benzer sonuçlara ulaşmıştır. Aynı zamanda Burul'un (2018) yaptığı çalışmada da öğretmen eğitiminde sorunlar olduğu sonucuna ulaşılmıştır. Öğretim programının uygulanmasında en büyük role sahip olan öğretmenlerin hizmet öncesi eğitimlerine önem verilerek programı sadece öğrenmekle kalmayıp sınıf içerisinde uygulama çalışmalarına da ağırlık verilmelidir.

Yapılan araştırmanın sonucunda, ortaokul öğretmenlerinin öğretim programına bağl11ık düzeylerinin cinsiyete göre anlamlı farklılık göstermediği ortaya çıkmıştır. Burul (2018) tarafından yapılan araştırmada da öğretmenlerin programa bağlılıklarının cinsiyete göre değişmediği tespit edilmiştir. Dolayısıyla kadın ve erkek ortaokul öğretmenlerin öğretim programına bağlılık düzeylerinin benzer olduğu söylenebilir. Araştırmada öğretim programına bağlılık ile ilgili olarak araştırılan bir diğer değişken 
mesleki deneyimdir. Yapılan analizler neticesinde öğretmenlerin öğretim programına bağl11ıklarının mesleki deneyime göre anlamlı düzeyde değişmediği belirlenmiştir. Bu sonuç öğretmenlerin göreve yeni başlamış olmaları ya da tecrübeli olmalarının öğretim programına bağlılık durumlarını etkilemediğini göstermektedir. Ayrıca, bu sonuç Burul (2018) ve Butakın ve Özgen'in (2007) yaptıkları çalışmalar ile benzerlik göstermektedir. Örneklem grubundaki öğretmenlerin çoğunluğunun eğitimlerini öğrenci merkezli programların geliştirildiği 2005 yılından sonra almış olmaları programa bağlılıklarının benzer olmasını beraberinde getirmiş olabilir. Ayrıca, 2005'ten günümüze geçen süre zarfında geleneksel anlayışa göre yetişen mesleki deneyimi fazla olan öğretmenler de yapılandırmacı yaklaşımı içselleştirmiş olabilir.

Öğretim programına bağlllık düzeyini etkileyebilecek bir diğer değişkenin eğitim düzeyi olabileceği düşünülmüştür. Bu doğrultuda yapılan analizler neticesinde öğretmenlerin öğretim programına bağlılık toplam puanlarının eğitim düzeyine göre değişmediği, alt boyutlar bazında ise farklı sonuçlara ulaşıldı̆̆ı belirlenmiştir. Ölçeğin uyma, süre, program farklılıkları, katılımcıların tepkileri, öğretmen eğitimi ve okul iklimi alt boyutlarında eğitim düzeyine göre anlamlı farklılık görülmezken, uygulamanın kalitesi boyutunda anlamlı farklılık saptanmıştır. Buna göre, lisansüstü eğitim mezunu olan öğretmenler lisans öğretmenlerine göre daha kaliteli uygulamalar yapmaya gayret etmektedir. Ayrıca, bu sonuçtan hareketle yüksek lisans ve doktora mezunu olan öğretmenlerin yapılandırmacı yaklaşımı ve öğrenci merkezli eğitimi lisans mezunu olan öğretmenlere göre daha fazla benimsedikleri ve öğretim sürecinde farklı yöntem-teknikler kullanmaya daha eğilimli oldukları söylenebilir. Alanyazın incelendiğinde Burul'un (2018) yaptığı çalışmada bu çalışmada ulaşılan sonucun aksine programa bağlılı̆̆ın eğitim düzeyine göre anlamlı bir farklılık göstermediği tespit edilmiştir.

Araştırmada incelenen bir diğer değişken görev yapılan yerleşim yeridir. Ortaokul öğretmenlerinin öğretim programına bağlılıklarının genel ortalamasında ve alt boyutlarında görev yapılan yerleşim yerine göre anlamlı bir farklılık tespit edilmemiştir. $\mathrm{Bu}$ bağlamda öğretmenlerin köy, ilçe ya da il merkezinde görev yapmalarına bağlı olarak öğretim programına bağlılık düzeylerinde anlamlı bir değişimin olmadığı söylenebilir. Çalışmada ulaşılan bu sonucun alanyazında kuramsal olarak ortaya konulan bilgilerle uyumlu olmadığı ifade edilebilir. Çünkü ilgili araştırmalarda (Bümen 
ve diğ., 2014; Ringwalt ve diğ., 2003) öğretim programına bağlılığın çevresel koşullar, sosyo-ekonomik durum, öğrenci profili ve okul bağlamı ile ilişkili olduğu ifade edilmiştir. Bu konuda daha çok çalışmanın yapılmasının, yapılan çalışmalarda farklı koşullarda programa bağlılığı etkileyen değişkenlerin araştırılmasının ve bu çalışmaların nitel verilerle desteklenmesinin konunun daha çok aydınlatılmasına katkı sunacağ söylenebilir.

Araştırmada son olarak öğretim programına bağlılığın branşa göre değişip değişmediği incelenmiştir. Yapılan analizler neticesinde uyma, süre, uygulamanın kalitesi, katılımcıların tepkileri ve program farklılıkları alt boyutlarında branşa göre anlamlı farklılık görülmezken, öğretmen eğitimi ve okul iklimi boyutlarında ve ölçek toplamında branşa göre anlamlı farklılık görülmüştür. Yapılan ikili karşılaştırmalar neticesinde teknoloji tasarım/bilişim teknolojileri öğretmenlerinin programa bağlılık düzeylerinin daha düşük olduğu, güzel sanatlar/beden eğitimi ve fen bilimleri öğretmenlerinin ise programa bağlılıklarının daha yüksek olduğu belirlenmiştir. Bay ve diğg. (2017) tarafından yapılan çalışmada öğretim programına bağlılı̆̆ı etkileyen bazı faktörlerin tüm branşlar için geçerli olduğu fakat branşın da programa bağlılıkta etkili olabileceği belirtilmiştir. Her programın kendisine has özellikleri olduğu düşünüldüğünde programa bağlılığın branşa göre farklılık göstermesinin beklenen bir sonuç olarak ifade edilebilir.

Araştırmada ulaşılan sonuçlardan yola çıkılarak aşağıda bazı önerilere yer verilmiştir:

- Lisansüstü eğitim yapan öğretmenlerin uygulamanın kalitesinden daha yüksek puanlar aldıkları dikkate alındığında, diğer öğretmenlerin de yüksek lisans ve doktora programlarına yönlendirilerek öğretim programına bağlılık düzeyinin arttırılması önerilebilir.

- Benzer çalışmalar nitel araştırma yöntemleri ile desteklenerek yapılabilir.

- Türkiye'nin farklı bölgelerinde görev yapan öğretmenlerin öğretim programına bağlılıkları karşılaştırmalı olarak incelenebilir. 


\section{Makalenin Bilimdeki Konumu}

Eğitim Bilimleri/Eğitim Programları ve Öğretim

\section{Makalenin Bilimdeki Özgünlüğü}

Alanyazın incelendiğinde yurtdışında öğretim programına bağlılık konusunun uzun yıllardır ele alındığı ve alınmaya devam edildiği görülmektedir. Türkiye'de ise program inceleme ve program değerlendirme ile ilgili çalışmaların yapıldığı, programa bağlılık ile ilgili çalışmaların çok sınırlı olduğu görülmektedir. $\mathrm{Bu}$ nedenle farklı koşullarda, farklı bölgelerde ve farklı branşlarda programa bağlılığın belirlenmesinin bir ihtiyaç olduğu ve alanyazına katkı sunacağı söylenebilir.

\section{Kaynaklar}

Akpınar, B. ve Aydın, K. (2007). Eğitimde değişim ve öğretmenlerin değişim algıları. Ĕ̈itim ve Bilim, 32(144), 71-80.

Akpınar, B. ve Gezer, B. (2010). Öğrenen merkezli yeni eğitim yaklaşımlarının öğrenme-öğretme sürecine yansımaları. Dicle University Journal of Ziya Gökalp Education Faculty, 14, 1-12.

Aslan, M. ve Erden, R. Z. (2018). Beşinci sınıf fen bilimleri öğretim programının değerlendirilmesi. Necatibey Eğitim Fakültesi Elektronik Fen ve Matematik Ĕ̈itimi Dergisi, 12(2), 508-537.

Aslan, M. ve Çıkar, İ. (2017). 4. sınıf matematik öğretim programının Tyler'ın hedefe dayalı program değerlendirme modeline göre değerlendirilmesi. Necatibey Ĕ̆itim Fakültesi Elektronik Fen ve Matematik Eğitimi Dergisi, 11(2), 172-196.

Aslan, M. ve Çökük, K. (2018). 2013 4. Sınıf Fen Bilimleri Dersi Öğretim Programı'nın Ünite Bazlı Değerlendirilmesi. Amasya Üniversitesi Eğitim Fakültesi Dergisi, 7(1), 156-192. 
Atilla, M. E. (2012). Fen ve teknoloji dersi öğretim programındaki yapılandırmacılı̆̆a dayalı öğelerin ögretmenler tarafından algılanışı ve uygulanışı. Yayınlanmamış Doktora Tezi, Atatürk Üniversitesi, Erzurum.

Aykaç, N. ve Ulubey, Ö. (2012). Öğretmen adaylarının ilköğretim programının uygulanma düzeyine ilişkin görüşleri. Ankara Üniversitesi Eğitim Bilimleri Fakültesi Dergisi, 45(1), 63-82.

Baki, A. (2010). Öğretmen eğitiminin lisans ve lisansüstü boyutlardan değerlendirilmesi. İnönü Üniversitesi Eğitim Fakültesi Dergisi, 11(3), 15-31.

Bal, A. P. (2008).Yeni ilköğretim matematik öğretim programının öğretmen görüşleri açısından değerlendirilmesi. Çukurova Üniversitesi Sosyal Bilimler Enstitüsü Dergisi, 17(1), 53-68.

Baş, G. ve Şentürk, C. (2017). Öğretme-öğrenme anlayışları ve öğretim programına bağlılık: İlişkisel bir araştırma. 1.Uluslararası Sosyal Bilimler Ĕgitim Araştırmaları Sempozyumu, 3-5 Kasım, Antalya. www.nobelyayin.com/sunumlar/iscer-ozet-2017.pdf adresinden $\quad$ 14.04.2019 tarihinde alınmıştır.

Bay, E., Kahramanoğlu, R., Döş, B. ve Turan-Özpolat, E. (2017). Programa bağlılı̆̆1 etkileyen faktörlerin analizi. Mehmet Akif Ersoy Üniversitesi Eğitim Fakültesi Dergisi, 43, 110-137.

Burul, C. (2018). Öğretmenlerin eğitim programı tasarım yaklaşımı tercihlerinin öğretim programına bağlılıklarıyla olan ilişkisinin incelenmesi. Yayınlanmamış Yüksek Lisans Tezi, Balıkesir Üniversitesi, Balıkesir.

Butakın, V. ve Özgen, K. (2007). Yeni ilköğretim matematik dersi öğretim programının (4. ve 5. sınıf) uygulamadaki etkililiğinin değerlendirilmesi: 
Diyarbakır ili örneği. Dicle Üniversitesi Ziya Gökalp Eğitim Fakültesi Dergisi, 8, $82-94$.

Bümen, N. T., Çakar, E. ve Yıldız, D. G. (2014). Türkiye'de öğretim programına bağlılık ve bağl1lı̆̆ etkileyen etkenler. Kuram ve Uygulamada Ĕ̆itim Bilimleri, 14(1), 203-228.

Büyüköztürk, Ş., Kılıç-Çakmak, E., Akgün, Ö.E., Karadeniz, Ş. ve Demirel, F. (2016). Bilimsel araştırma yöntemleri. Ankara: Pegem Akademi

Caner, A. ve Tertemiz, N. (2010). Uygulamayı etkileyen faktörler açısından ilköğretim 1. kademe öğretim programları uygulamalarının değerlendirilmesi: Sınıf öğretmeni görüşleri. Türkiye Sosyal Araştırmalar Dergisi, 14(2), 155-187.

Çelik-Şen, Y. ve Şahin-Taşkın, Ç. (2010). Yeni ilköğretim programının getirdiği değişiklikler: Sınıf öğretmenlerinin düşünceleri. Yüzüncü Yıl Üniversitesi Eğitim Fakültesi Dergisi, 6(2), 26-51.

Çiftçi, O. ve Tatar, E. (2015). Güncellenen ortaöğretim matematik öğretim programı hakkında öğretmen görüşleri. Turkish Journal of Computer and Mathematics Education (TURCOMAT), 6(2), 285-298.

Çiftçi, Z. B., Akgün, L. ve Deniz, D. (2013). Dokuzuncu sınıf matematik öğretim programı ile ilgili uygulamada karşılaşılan sorunlara yönelik öğretmen görüşleri ve çözüm önerileri. Anadolu Journal of Educational Sciences International, 3(1), $1-21$.

Çiftçioğlu, R. (2009). İlköğretim beşinci sınıffen ve teknoloji dersi öğretim programının uygulanmasına yönelik öğretmen görüşlerinin incelenmesi. Yayınlanmamış Yüksek Lisans Tezi, Kahramanmaraş Sütçü İmam Üniversitesi, Kahramanmaraş. 
Dikbayır, A. ve Bümen, N. (2016). Dokuzuncu sınıf matematik dersi öğretim programına bağlılığın incelenmesi. International Journal of Curriculum and Instructional Studies, 6(11), 17-38.

Dinç, E. ve Doğan, Y. (2010). İlköğretim ikinci kademe sosyal bilgiler öğretim programı ve uygulanması hakkında öğretmen görüşleri. Sosyal Bilgiler Eğitimi Araştırmaları Dergisi, 1(1), 17-49.

Dusenbury, L., Brannigan, R., Falco, M. ve Hansen, W. B. (2003). A review of research on fielity of implementation: Implications for drug abuse prevention in school settings. Health Education Research, 18(2), 237-256.

Ertürk, S. (1984). Eğitimde program geliştirme (5.baskl). Ankara: Yelkentepe Yayınları.

Gömleksiz, M. N. ve Bulut İ. (2007). Yeni fen ve teknoloji dersi öğretim programının uygulamadaki etkililiğinin değerlendirilmesi. Hacettepe Üniversitesi Ĕ̆itim Fakültesi Dergisi, 32, 76-88.

Gözütok, D. (2003). Türkiye'de program geliştirme çalışmaları. Milli Eğitim Dergisi 160, 44-64.

Gülbaş-Çatak, Ç. (2008). Yeni ilköğretim 1. sınıf ilk okuma yazma dersi öğretim programı uygulanmasına yönelik öğretmen görüşleri. Yayınlanmamış Yüksek Lisans Tezi, Muğla Üniversitesi, Muğla.

Güneş, B. ve Baki, A. (2011). Dördüncü sınıf matematik dersi öğretim programının uygulanmasından yansımalar. Hacettepe Üniversitesi Eğitim Fakültesi Dergisi, 41, 192-205. 
Güzel, A. ve Karadağ, Ö. (2013). Anlatma becerileri açısından “Türkçe Dersi Öğretim Programı (6,7,8. Sınıflar)"na eleştirel bir bakış. Ana Dili Eğitimi Dergisi, 1(1), 4552.

Han, Ç. (2013). Öğretmenlerin işlevsel paradigmaları ve eğitim reformu. Trakya Üniversitesi Ĕ̈itim Fakültesi Dergisi, 3(1), 59-79.

Kamber, T., Acun, Ġ. ve Akar, C. (2011). İlköğretim birinci kademe sosyal bilgiler öğretim programının uygulanabilirliği. Uşak Üniversitesi Sosyal Bilimler Dergisi, $4(2), 195-218$.

Karacaoğlu, C. ve Acar, E. (2010). Yenilenen programların uygulanmasında öğretmenlerin karş1laştı̆̆ sorunlar. Yüzüncü Yıl Üniversitesi Eğitim Fakültesi Dergisi, 7(1), 45-58.

Karasar, N. (2005 ). Bilimsel araştırma yöntemi. Ankara: Nobel Yayın Dağıtım.

Kaya N., Artvinli, E. ve Bulut İ. (2008). 2005 y1lı coğrafya öğretim programının uygulanma düzeyi: 9. sınıf coğrafya programı örneği. Balıkesir Üniversitesi Sosyal Bilimler Enstitüsü Dergisi, 11(19), 40-59.

Kenan, O. ve Özmen, H. (2010). Bir reform olarak yeni ögretim programlart. II. Uluslararası Eğitim Araştırmaları Kongresi'nde sunulan bildiri, Çanakkale 18 Mart Üniversitesi, Antalya.

Kovaleski, J. F., Gickling, E. E., Morrow, H. ve Swank, H. (1999). High versus low implementation of instructional support teams: A case for maintaining program fidelity. Remedial and Special Education, 20, 170-183.

Kozikoğlu, İ. (2014). Ortaokul 7.sınıf İngilizce öğretim programının değerlendirilmesi. Bolu Abant İzzet Baysal Üniversitesi Eğitim Fakültesi Dergisi, 14 (1), 361-375. 
Kurt, S. ve Yıldırım, N. (2010). Ortaöğretim 9. sınıf kimya dersi öğretim programının uygulanması ile ilgili öğretmenlerin görüşleri ve önerileri. On dokuz Mayls Üniversitesi Ĕ̆itim Fakültesi Dergisi, 29(1), 91 -104.

Marsh, C. J. ve Willis, G. (2007). Curriculum: Alternative approaches, ongoing issues. Upper Saddle River, N. J.: Merrill / Prentice Hall.

Meşin, D. (2008). Yenilenen altıncı sınıf matematik öğretim programının uygulanması sürecinde öğretmenlerin karşılaştıkları sorunlar. Yayınlanmamış Yüksek Lisans Tezi, Sakarya Üniversitesi, Sakarya.

Özçelik, D. A. (1992). Eğitim programları ve ögretim. Ankara: ÖSYM Yayınları.

Öztürk, İ. H. (2012). Öğretimin planlanmasında öğretmenin rolü ve özerkliği: Ortaöğretim tarih öğretmenlerinin yıllık plan hazırlama ve uygulama örneği. Kuram ve Uygulamada Ĕ̈itim Bilimleri, 12, 271-299

Öztürk, E. ve Demircioğlu, H. (2002). Lise biyoloji öğretim programı uygulanmasında öğretmen rolü. 5. Ulusal Fen Bilimleri ve Matematik Eğitimi Kongresi, 16-18 Eylül 2002, Ankara, Bildiriler, Cilt 1, 122-128.

Öztürk-Akar, E. (2005). Lise biyoloji dersi öğretim programının uygulanmasında okul düzeyinde görülen farkl11ıklar. Eğitim Bilimleri ve Uygulama, 4(7), 51-67.

Pence, K. L., Justice, L. M. ve Wiggins, A. K. (2008). Preschool teachers' fidelity in implementing a comprehensive language-rich curriculum. Language, Speech, and Hearing Services in Schools, 39, 329-341.

Ringwalt, C. L., Ennett, S., Johnson, R., Rohrbach, L. A., Simons-Rudolph, A., Vincus, A. ve Thorne, J. (2003). Factors associated with fidelity to substance use prevention curriculum guides in the nation's middle schools. Health Education \& Behavior, 30(3), 375-391. 
Taşçı, Ş. (2011). Fizik öğretim programının uygulanmasının değerlendirilmesi. Yayınlanmamış Yüksek Lisans Tezi, Karadeniz Teknik Üniversitesi, Trabzon.

Tekbıyık, A. ve Akdeniz, A. R. (2008). İlköğretim fen ve teknoloji dersi öğretim programını kabullenmeye ve uygulamaya yönelik öğretmen görüşleri. Necatibey Ĕ̌itim Fakültesi Elektronik Fen ve Matematik Eğitimi Dergisi, 2(2), 23-37.

Uşun, S. (2016). Eğitimde program değerlendirme süreçler-yaklaşımlar ve modeller (2.baskl). Ankara: Anı Yayıncıl1k.

Yaşaroğlu, C. ve Manav, F. (2015). Öğretim programına bağlilık ölçeği: Geçerlilik ve güvenirlik çalışması. Uluslararası Eğitim Bilimleri Dergisi, 2(4), 247-258.

Zengin, M. (2010). Yeni ilköğretim DKAB öğretim programının uygulamadaki etkililiğinin değerlendirilmesi. Sakarya Üniversitesi İlahiyat Fakültesi Dergisi, 12(22), $121-160$. 


\section{Summary}

\section{Introduction}

Regional conditions, curriculum characteristics, teacher education, institutional characteristics, socio-economic status, student characteristics, examinations and education system can be considered as factors affecting the implementation of the curriculum (Bümen, Çakar \& Y1ldız, 2014). Ringwalt et al. (2003) stated that the factors affecting the curriculum fidelity are the school context, the system in which the program is applied, program practitioners (teachers) and the target audience (students). Therefore, it can be said that one of the most important factors affecting the curriculum fidelity is the teachers implementing the curriculum. Teachers should plan and implement in-class activities in line with the students' level with their own experience and competencies, based on the curriculum. It is important to determine the extent to which the curriculum is adopted and reflected by the teachers in terms of labor, money and time spent (Dikbayır \& Bümen, 2016). In this context, the aim of this study is to investigate the curriculum fidelity of secondary school teachers according to various variables. For this purpose, the following questions were sought:

1. What is the level of teachers' curriculum fidelity?

2. Do teachers' commitment to the curriculum differ significantly by gender, professional experience, educational level, place of residence, and branch?

\section{Method}

The screening model was used in the research. The sample of the study consists of 356 teachers working in villages, districts and central secondary schools of Van province in 2018-2019 academic year. Participant teachers consisted of $180(50.6 \%)$ female and $176(49.4 \%)$ male. $202(56.7 \%)$ of the participants were working in the city center, $109(30.6 \%)$ were working in the districts and $45(12.6 \%)$ were working in the villages. The distribution of teachers according to branches was as follows: Mathematics $(\mathrm{n}=62)$, English $(\mathrm{n}=39)$, Science $(\mathrm{n}=48)$, Fine Arts/Physical Education $(\mathrm{n}=49)$, Social Studies $(\mathrm{n}=43)$, Religious Culture and Ethics $(\mathrm{n}=26)$, Turkish $(\mathrm{n}=$ $59)$ and Technology Design/Information Technologies $(n=30)$.

In the study, "Curriculum Fidelity Scale" was used as data collection tool. The scale developed by Burul (2018) consists of 7 sub-dimensions (compliance, dose / time, quality of application, the reactions of the participants, program differences, teacher education and school climate). In this study, Cronbach's Alpha value was found as .81. These value indicate that the data obtained from the measurement tool is reliable. Descriptive statistics (mean and standard deviation), independent samples t test and oneway ANOVA were used in the data analysis. In case ANOVA test revealed a significant difference, LSD Test was used for pairwise comparisons. The significance level was accepted as .05 .

\section{Findings}


It was determined that the arithmetic mean of the teachers' curriculum fidelity was 3.55. In terms of sub-dimensions, the mean of the compliance dimension was 3.42 ; the mean of the time dimension was 3.34; the mean of the quality of the application was 4.07; the mean of the responses of the participants was 3.90; the mean of the program differences was 3.34; the mean of the teacher education dimension was 3.27 and the mean of school climate dimension was 3.55.

It was found that the secondary school teachers' curriculum fidelity did not show a significant difference according to gender, seniority and place of residence in total scale and in any sub-dimension $(\mathrm{p}>.05)$. On the one hand, it was found that the secondary school teachers' curriculum fidelity showed a significant difference according to education level in the quality of application dimension $(\mathrm{p}<.05)$. Also, it was found a significant difference according to branch variable in the teacher education dimension, school climate dimension and total scale.

\section{Discussion and Conclusion}

As a result of the study, it was seen that the secondary school teachers generally had a high level of curriculum fidelity. In the literature, research results consistent with this result (Akpınar \& Aydın, 2007, Burul, 2018; Çelik-Şen \& Şahin-Taşkın, 2010; Kenan \& Özmen, 2010; Öztürk, 2012; Tekbıyık \& Akdeniz, 2008) were reached. On the contrary, in the studies conducted by Atilla (2012), Han (2013) and Aykaç \& Ulubey (2012), it was determined that the level of teachers' curriculum fidelity was low. When examined on the basis of sub-dimensions, it was determined that the most positive opinions relate with "the quality of the application" and "the reactions of the participants"; the most negative opinions relate with "time" and "teacher education" dimensions. It was concluded that the curriculum fidelity of secondary school teachers did not differ significantly according to gender, seniority and place of residence. On the other hand, it was determined that teachers' curriculum fidelity differed significantly according to education level and branch variables. 